\title{
The Effects of Hevea Bransiliensis Natural Rubber on Kidney Free and Total Cholesterol Concentrations of Experimental Rats
}

\author{
${ }^{1}$ Bawa Abubakar, ${ }^{2}$ Njoku O. U., ${ }^{3}$ Salihu Suleiman, ${ }^{2}$ Joshua Parker E., ${ }^{2}$ Agu \\ Chidozie V.And ${ }^{2}$ Okonkwo C. C. \\ ${ }^{I}$ Department of Preliminary and Remedial Studies, Federal Polytechnic Mubi, Adamawa State, Nigeria. \\ ${ }^{2}$ Department of Biochemistry, University Of Nigeria, Nsukka, Enugu State Nigeria. \\ ${ }^{3}$ Department of Chemistry, Federal University Dutse, Jigawa State, Nigeria.
}

\begin{abstract}
The effects of Hevea bransiliensis natural rubber on kidney free and total cholesterol concentration of experimental rats were analyzed. Forty albinos wister rats of either sex weighing 140-450g were used. The rats were divided into five equal groups marked $A, B, C, D$ and $E$ of eight rats each, and each group was fed on different dietary regime $A, B, C, D$ and $E$ respectively as indicated in tables 1 and 2. Diet $A$, (the control) had no rubber seed oil in the diet, whereas diets B, C, D and $E$ (the experimental) had $2 \%$ refined rubber seed oil, $2 \%$ crude rubber seed oil, $4 \%$ refined rubber seed oil and $4 \%$ crude rubber seed oil by weight incorporated respectively. The results showed that the increase in mean kidney total cholesterol level was greater in group $B$ ( $2 \%$ refined rubber seed oil incorporated diet) followed with groups A (control), $C$ ( $2 \%$ crude rubber seed oil), $E$ ( $4 \%$ crude rubber seed oil) and D (4\% refined rubber seed oil) incorporated diets for the corresponding weeks. The results also showed an increase in kidney free cholesterol level throughout the period of experiment. It was observed that the increase in mean kidney free cholesterol level was greater in groups E and C $(4 \%$ and $2 \%$ crude rubber seed oil incorporated diets) than group A control, B (2\% refined seed oil incorporated diets) and $D(4 \%$ refined rubber seed oil) for the corresponding weeks. Group D animals showed very little increase in mean kidney free cholesterol level as indicated in Table 4.
\end{abstract}

Keywords: Hevea bransiliensis, Natural rubber, Kidney and Cholesterol.

\section{Introduction}

Cholesterol is the main sterol of animal tissues and consequently, foods that are derived from animal products contain cholesterol [1]. It is always found in vertebrates and in some invertebrates but not in plants. In plants it is replaced by $\beta$ - sitosterol [2]. The distribution of cholesterol between tissues and body fluids depend on the degree of saturation of the serum fatty acids. Saturated fatty acid in the diet increases plasma cholesterol level which poly unsaturated fatty acids don't [3]. The indication is that more cholesterol is associated with the tissues when the diet is rich in poly unsaturated fatty acids [3]. Unlike cholesterol, plants sterols like $\beta-$ sitosterol are absorbed poorly and this fact is useful clinically because $\beta$ - sitosterol can be administered to patients with hypercholesterolemia in an attempt to reduce cholesterol absorption [4].

Natural rubber, (Hevea brasiliensis and Fantumia elastica) are two species of rubber tree found in the humid belt of the tropics. The latter species appears to have a more restricted geographic distribution to the lowland rainforest belt of West Africa, whereas Hevea brasiliensis extends in the humid tropical belt from Brazil in the West, through West and Central Africa to India, Malaysia and Indonesia in the East [5].

\section{Materials}

\section{Meterial And Methods}

Forty albino wister rats of either sex weighing $140-450 \mathrm{~g}$ were used for this analysis. The rats were obtained from the animal house of National Institute of Trypanosomonas Research Centre, Vom in Plateau State, Nigeria. They were kept in stainless steel cages with raised wire floors in a room maintained at $37^{\circ} \mathrm{C}$. The animals were fed for a period of 12 weeks. The rats were divided into five equal groups marked A, B, C, D and $\mathrm{E}$ of eight rats each, and each group was fed on different dietary regime A, B, C, D and E respectively as indicated in tables 1 and 2. Diet A, (the control) has no rubber seed oil in the diet, whereas diets B, C, D and E (the experimental) had 2\% refined rubber seed oil, $2 \%$ crude rubber seed oil, $4 \%$ refined rubber seed oil and $4 \%$ crude rubber seed oil by weight incorporated respectively.

The rats were initially starved for $24 \mathrm{~h}$ before being fed adlibitum with the various diets. Measurement of the liver cholesterol levels were carried out at the beginning of the experiment and subsequently at the end of every four weeks throughout the period of experiment, except the histochemical investigation of the liver that was done initially at the end of three months. 
Table 1: Feeding patterns with rubber seed oil incorporated diet

(Njoku, O.U. and Ononogbu, I.C., 1996).

\begin{tabular}{|c|c|c|c|c|c|}
\hline $\begin{array}{l}\text { Group/Treatment of } \\
\text { Rations \% }\end{array}$ & $\mathrm{A}$ & $\mathrm{B}$ & $\mathrm{C}$ & $\mathrm{D}$ & $\mathrm{E}$ \\
\hline Maize flour & 70 & 68 & 68 & 66 & 66 \\
\hline Fish meal & 10 & 10 & 10 & 10 & 10 \\
\hline Groundnut cake & 20 & 20 & 20 & 20 & 20 \\
\hline Ruber seed oil & - & 2 & 2 & 4 & 4 \\
\hline
\end{tabular}

Table 2: Components of rat feed/100g edible portion modified by (Njoku, O.U. and Ononogbu, I.C., 1996).

\begin{tabular}{|l|l|l|l|l|l|l|l|}
\hline & Water (ml) & Protein (gm) & Fat (gm) & $\begin{array}{l}\text { Carbohydrate } \\
(\mathrm{gm})\end{array}$ & Fibre (gm) & Mineral (gm) & Vitamin (gm) \\
\hline Maize flour & 12 & 10 & 4.5 & 71 & 2.0 & 14.5 & 2.48 \\
\hline $\begin{array}{l}\text { Groundnut } \\
\text { cake }\end{array}$ & 6 & 27 & 45 & 17 & 3.0 & 52.5 & 18.05 \\
\hline Fish meal & 20 & 63 & 6.3 & - & - & 3008 & 6.3 \\
\hline $\begin{array}{l}\text { Rubber seed } \\
\text { oil }\end{array}$ & 3.98 & 22.30 & 42.6 & - & 4.20 & 2.9 & - \\
\hline
\end{tabular}

\section{EXTRACTION OF RAT BLOOD PLASMA}

Five rats from each group were anaesthetized with chloroform and blood was withdrawn by cardiac puncture. Just before anesthesia, light was shone on the rats to increase the rate of blood flow into the syringe tubes. $3 \mathrm{ml}$ of blood drawn into EDTA (3 drops per $1.0 \mathrm{ml}$ of blood was centrifuged for 10 minutes at 10,000g and the plasma (straw coloured liquid) which rises to the top was removed by Pasteur pipette as not to disturb the buffy layer of blood cells. The plasma was stored at $4^{\circ} \mathrm{C}$ until analysis and was analyzed within two days of extraction.

\section{KIDNEY TOTAL AND FREE CHOLESTEROL DETERMINATION}

The kidney was equally excised, placed in a small pre-weighed beaker. The kidney was homogenized in phosphate buffer $\mathrm{pH} 6.2$ and the lipid was recollected using chloroform-acetone mixture. The kidney cholesterol concentrations were determined as in the plasma cholesterol by using the homogenate.

\section{Results}

Table 3: Mean kidney total cholesterol concentration $(\mathrm{mg} / 100 \mathrm{ml})$

\begin{tabular}{|l|l|l|l|l|l|}
\hline \multicolumn{5}{|l|}{} \\
\hline Weeks & Groups & B & C & D & E \\
\hline 0 & $45.0 \pm 5.00$ & $46.0 \pm 1.50$ & $43.0 \pm 2.00$ & $39.0 \pm 1.00$ & $44.0 \pm 2.50$ \\
\hline 4 & $75.0 \pm 5.00$ & $80.25 \pm 0.25$ & $75.25 \pm 5.25$ & $55.0 \pm 5.00$ & $70.0 \pm 10.00$ \\
\hline 8 & $65.0 \pm 5.00$ & $66.5 \pm 8.50$ & $58.0 \pm 1.50$ & $45.0 \pm 5.00$ & $54.0 \pm 4.00$ \\
\hline 12 & $60.0 \pm 0.50$ & $50.0 \pm 1.00$ & $45.0 \pm 5.00$ & $35.0 \pm 5.00$ & $45.0 \pm 4.50$ \\
\hline
\end{tabular}

Table 4: Mean kidney free cholesterol concentration $(\mathrm{mg} / 100 \mathrm{ml})$

\begin{tabular}{|l|l|l|l|l|l|}
\hline \multicolumn{2}{|l|}{ Groups } & B & B & C & D \\
\hline Weeks & A & $39.5 \pm 2.00$ & $40.0 \pm 3.00$ & $35.0 \pm 2.00$ & E \\
\hline 0 & $41.0 \pm 1.50$ & $54.0 \pm 2.00$ & $48.0 \pm 4.00$ & $42.0 \pm 2.00$ & $36.0 \pm 2.50$ \\
\hline 8 & $34.5 \pm 1.50$ & $42.0 \pm 2.00$ & $38.0 \pm 2.00$ & $40.0 \pm 0.50$ & $48.0 \pm 4.00$ \\
\hline 12 & $45.5 \pm 1.50$ & $40.0 \pm 4.00$ & $40.0 \pm 0.50$ & $33.5 \pm 1.50$ & $35.0 \pm 1.00$ \\
\hline
\end{tabular}

\section{Discussion}

Cholesterol levels in the kidney of the rats were determined during the course of the research and the values of mean kidney total cholesterol levels were shown in table 3 for the corresponding weeks of feeding the animals in various groups. The results indicated a general increase of kidney total cholesterol level with the duration of the feeding. It was, however, observed that the increase in mean kidney total cholesterol level was greater in group B ( $2 \%$ refined rubber seed oil incorporated diet) followed with groups A (control), C ( $2 \%$ crude rubber seed oil), E ( $4 \%$ crude rubber seed oil) and D (4\% refined rubber seed oil) incorporated diets for the corresponding weeks. Group D showed minimal increase in mean kidney total cholesterol level with the duration of feeding as shown in table 3.

Also mean kidney free cholesterol level of the rats was analyzed in the course of research and the levels were determined as shown in Table 4. The results showed an increase in kidney free cholesterol level throughout the period of experiment. It was observed that the increase in mean kidney free cholesterol level was greater in groups E and C (4\% and $2 \%$ crude rubber seed oil incorporated diets) than group A control, B (2\% 
refined seed oil incorporated diets) and D (4\% refined rubber seed oil) for the corresponding weeks. Group D animals showed very little increase in mean kidney free cholesterol level as indicated in Table 4.

\section{Conclusion}

In conclusion, the results showed an increase in total and free cholesterol concentrations throughout the duration of the analysis.

\section{References}

[1]. Njoku, O.U. and Ononogbu, I.C. (1996). Toxicology Studies of the rubber (Hevea brasiliensis) seed oil. West African J. Biol.Sc. 4(2): $135-140$.

[2]. Nwokolo, E. Kitts, D.D. and Kanhai, J. (1988). Serum and Liver Lipids of rats fed rubber seed oil. Plant Foods for Human Nutrition 38. Pp. $145-153$

[3]. Okonkwo, S.N.C. (1992). Biotechnology and Natural Resources Management Whydah Newsletter of Africa Academy of Science 3. No. 2. Pp. 1-10.

[4]. Okoye, W.I. (1986). Storage of Natural Rubber Seed Oil and Cakes: In Industrial Utilization of Natural Rubber (Hevea Brosiliensis) Seed, latex and rubber. Edt. Enahor, E.E. Rubber Research Institute of Nigeria, Benin City. Pp. 123-128.

[5]. Ononogbu, I.C., and C.N. Eleazu (1979). Plasma phospholipid changes in trick infested Nadama cattle. Res. Vet. Sci. $27 ., 123$. 